\title{
Anti-acetylcholinesterasic, antioxidant and antibacterial activities of Juniperus brevifolia extracts
}

\author{
Nemésia Oliveira ${ }^{1}$, Sofia Medeiros ${ }^{1}$, José Silvino Rosa ${ }^{1,2}$, Ana M. L. Seca ${ }^{3,4 *}$ and Maria Carmo Barreto ${ }^{3,5}$ \\ ${ }^{1}$ Departament of Biology, University of Azores, 9501-801 Ponta Delgada, Portugal \\ ${ }^{2}$ CIBIO-Açores, University of Azores, 9501-801 Ponta Delgada, Portugal \\ ${ }^{3}$ DCTD, University of Azores, 9501-801 Ponta Delgada, Portugal \\ ${ }^{4}$ QOPNA, University of Aveiro, 3810-193 Aveiro, Portugal \\ ${ }^{5}$ CIRN, University of Azores, 9501-801 Ponta Delgada, Portugal
}

\begin{abstract}
Juniperus brevifolia (Seub.) Antoine (Cupressaceae) is an endemic conifer of the Azores, a habitat isolated from the continental masses which may significantly influence the biosynthesis of bioactive compounds with unique features. In this context, the toxicity, antibacterial, antioxidant (DPPH) and anti-acetylcholinesterasic (anti-AChE) activities of the methanol and acetone extracts of J. brevifolia wood and bark were evaluated for the first time. In the brine-shrimp assay all the extracts showed low toxicity, with the concentration causing $50 \%$ mortality $\left(\mathrm{LC}_{50}\right)$ higher than $2.03 \mathrm{mg} / \mathrm{mL}$. The acetone extract of the bark proved to be the most active against Bacillus cereus, B. subtilis and Micrococcus luteus, while the wood acetone extract showed activity only against B. cereus. No activity was observed against Gram (-) bacteria Escherichia coli and Enterobacter cloacae. The acetone extract of bark was the most active showing the higher antioxidant $\left(\mathrm{EC}_{50}=7.0 \mu \mathrm{g} / \mathrm{mL}\right)$ and antiAChE activities $\left(\mathrm{IC}_{50}=193 \mu \mathrm{g} / \mathrm{mL}\right)$, near to the reference compounds, quercetin $\left(\mathrm{EC}_{50}=3.2 \mu \mathrm{g} / \mathrm{mL}\right)$ and ursolic acid (IC $\left.{ }_{50}=190 \mu \mathrm{g} / \mathrm{mL}\right)$, respectively. The present study demonstrates the great potential of the acetone bark extract of J. brevifolia as a source of new non-toxic natural bioactive compounds as antioxidant and antiacetylcholinesterasic drugs.
\end{abstract}

\section{Introduction}

The genus Juniperus is the only genus from the Cupressaceae family that grows spontaneously in Europe [1]. Although some Juniperus species have toxic effects, they have also many uses in folk medicine in several parts of the world, such as antitussive, hypoglycaemic and in the treatment of cold, urinary infection, urticarial rash, dysentery, hemorrhage, leukorrhea and rheumatic arthritis [1]. Juniperus brevifolia (Seub.) Antoine belongs to this genus and is the only conifer endemic to the Azores. Previously published results showed that leaves extracts, for instance the dichloromethane extract and the chloroformsoluble fraction of the acetone extract, are very active against HeLa and Hep-2 tumour cell lines [2].

Natural products have made significant contributions towards the treatment of degenerative diseases [3]. Among these, acetylcholinesterase inhibitors (AChEI) have lately become a very active research topic because they increase the level of acetylcholine (ACh), which is abnormally low in disorders associated with cognitive processes, memory and neuromuscular activity [4]. Due to this fact, AChEIs have application in the treatment of Alzheimer's disease [5], to combat myasthenia gravis, glaucoma, and as antidotes to toxins [6]. Many natural compounds from plants, with a wide diversity of structural features, are AChEIs [7]. Oxidative stress, reactive oxygen species (ROS) and reactive nitrogen species (RNS) are involved in cancer, aging process, inflammation, cardiovascular disease and central nervous system degeneration $[8,9]$. Therefore, the research on new natural AChEIs and radical scavenging agents is considered very important to pharmaceutical, cosmetic and food industries.
One of the most interesting fields of application for plant extracts is the inhibition of growth and reduction in numbers of food-borne pathogens like Bacillus cereus and Escherichia coli [10]. On the other hand, bacteria are becoming increasingly resistant to antibiotics [11] and therefore efforts to discover new bacterial agents must continue.

In this work we report, for the first time, the screening of DPPH, anti-acetylcholinesterase and antibacterial activities and toxicity of the acetone and methanol extracts from bark and wood of J. brevifolia.

\section{Materials and methods}

\section{Drugs and reagents}

Reference compounds [butylated hydroxytoluene (BHT), quercetin, ursolic acid, gentamicin, chloramphenicol], acetylcholinesterase from Electrophorus electricus and reagents [2,2-diphenyl-1-picrylhydrazyl (DPPH), acetylthiocholine iodide, 5,5'-dithiobis-2-nitrobenzoic acid (DTNB)] were purchased from Sigma-Aldrich. All other chemicals and solvents were purchased from Panreac and Acros Organics and were of analytical grade or bi-distillate commercial solvents.

Correspondence to: Ana M. L. Seca, Department of Technologic Sciences and Development, University of Azores, Rua Mãe de Deus, 9501-801 Ponta Delgada, Portugal; E-mail: anaseca@uac.pt

Key words: Juniperus brevifolia, Cupressaceae, acetone extract, antiacetylcholinesterase, antioxidant

Received: February 20, 2015; Accepted: March 24, 2015; Published: March 27, 2015 


\section{Plant material}

The bark and wood of Juniperus brevifolia (Seub.) Antoine were harvested in Pedreira, Nordeste, São Miguel, Azores, in June/2001. The voucher specimen was identified by Prof. Maria João Pereira of University of Azores and a voucher was deposited at Ruy Telles Palhinha Herbarium (AZB), University of Azores, under the reference AZB-Ana Seca-1.

\section{Preparation of the extracts}

The extracts were obtained as described by Moujir et al. [2]. Briefly, air-dried materials (517 $\mathrm{g}$ of bark and $1560 \mathrm{~g}$ of wood) were finely grounded to 40 mesh and extracted successively with hexane, dichloromethane, acetone and methanol using a soxhlet apparatus (24 $\mathrm{h}$ each). The acetone and methanol were evaporated under reduced pressure yielding (g extract $/ 100 \mathrm{~g}$ vegetable material) $16.5 \%$ of acetone extract from bark (AB) and 1.2\% from wood (AW), 3.6\% of methanol extract from bark (EB) and $0.8 \%$ from wood (EW). Stock solutions from the extracts, dissolved in methanol, were prepared for the assays.

\section{Acetylcholinesterase inhibition}

The anti-AChE activity determination was assessed following the assay described by [12] at $\mathrm{pH} 8.0$ and using acetylthiocholine iodide as substrate, in the presence of buffer containing DTNB and extract in different concentrations. The reaction was followed for $7.5 \mathrm{~min}$ at 415 $\mathrm{nm}$, using a Bio-Rad Model 680 Microplate reader. Every experiment was done in triplicate.

\section{DPPH radical scavenging assay}

Antioxidant activity was assayed by the DPPH radical scavenging assay [13]. Different concentrations of plant extracts were added to the assay medium containing DPPH solution, allowed to stand in the dark for $30 \mathrm{~min}$ and the absorbance at $515 \mathrm{~nm}$ measured and compared with control absorbance without the extract samples. Antioxidant activity percentage (AA\%) was calculated as $\mathrm{AA} \%=1-(\mathrm{Ac}-\mathrm{As}) / \mathrm{Ac} \times 100$, where Ac is the absorbance of control and As is the absorbance of each sample. Quercetin was used as reference compound. All assays were carried out in triplicate and results expressed as $\mathrm{EC}_{50}$.

\section{Antibacterial assay}

Inoculums in $0.85 \%$ sterile saline $(\mathrm{NaCl})$ were prepared from cultures of Gram(+) Bacillus subtilis (DSM 10), B. cereus (DSM31), Micrococcus luteus (DS 420030) and Gram(-) Escherichia coli (DSM 498) and Enterobacter cloacae (DSM 30850). The resulting suspension was diluted to obtain a turbidity comparable to 0.5 in the McFarland Scale (bioMerieux ${ }^{\oplus}$, France), i.e., equivalent to approximately $1.5 \times 10^{6}$ $\mathrm{CFU} / \mathrm{mL}$.

The antibacterial assay was performed by a modification of Bauer's diffusion technique [14] on solid medium using $6 \mathrm{~mm}$ filter paper discs. $200 \mu \mathrm{g}$ of each extract dissolved in methanol $(10 \mu \mathrm{L}$ of a $20 \mathrm{mg}$ / $\mathrm{mL}$ solution) was added to a disc which was placed on the agar after evaporation of the solvent, and the diameter of inhibition around the disc was recorded after $24 \mathrm{~h}$. Gentamicin and chloramphenicol were used as positive controls.

\section{In vitro Artemias alina toxicity assay}

The methodology described by Solis et al. [15] was used with some modifications. Briefly, $200 \mu \mathrm{L}$ of seawater containing different concentrations of the extracts $(1-2.5 \mathrm{mg} / \mathrm{mL})$, prepared by dilution of different amounts of the methanolic stock solutions in filtered sea water, were placed in each well of a 96-well microplate and 15-20 Artemia salina nauplii were added to each well. Two types of control were used, one with methanol and another with potassium dichromate. The microplates were incubated at $25^{\circ} \mathrm{C}$ for $24 \mathrm{hrs}$, examined under the stereoscopic microscope (12.5X), and the dead individuals (i.e., without movement) were numbered. Subsequently, $50 \mu \mathrm{L}$ of acetone were added to each well and after $15 \mathrm{~min}$ the total number of nauplii was counted. Each extract was tested in triplicate.

\section{Statistical analysis}

Each biological test was performed in triplicate. Comparisons of $\mathrm{IC}_{50}$ or $\mathrm{EC}_{50}$ values from different samples were performed using oneway ANOVA. Tukey-Kramer's post-test was used. A $P$ value lower than 0.05 was considered statistically significant.

\section{Results and discussion}

The role of AChE inhibitors in the therapeutic of Alzheimer's disease is important as the most damaged parts of the CNS are cholinergic [6]. However, several adverse effects have been reported with the currently available AChE inhibitors, therefore it is necessary to explore new drug candidates [9].

In this context, the methanolic and acetone extracts from wood and bark of J. brevifolia were assayed as AChE inhibitors and the results are presented on Table 1.

Although the bark and wood methanolic extracts and the wood acetone extract showed low inhibitory effect against acetylcholinesterase (AChE), the acetone extract from bark exhibited a very significant antiAChE activity, near to the reference compound ursolic acid (the null hypothesis is true with $P>0.05$ ). In fact, this extract was more active than the phenolic-enriched fractions obtained from other Juniperus species found in Portugal, none of which achieves 50\% of inhibition at $200 \mu \mathrm{g} / \mathrm{mL}[16]$.

DPPH is a free-radical (2,2-diphenyl-1-picrylhydrazyl) that has been widely used to determine free-radical-scavenging ability (Table 1). With regard to $\mathrm{EC}_{50}$ values (the concentration of antioxidant required to achieve an absorbance equal to $50 \%$ that of a control containing no antioxidants), all of the tested extracts were much more active than extracts from fruits and leaves of several Turkish Juniperus species assayed by the same method $[17,18]$. The methanolic extract of bark showed a free-radical-scavenging ability near that of $\mathrm{BHT}\left(\mathrm{EC}_{50}=31.0\right.$ $\mu \mathrm{g} / \mathrm{mL})(P>0.05)$ while that exhibited by acetone extracts was near the value of quercetin $\left(\mathrm{EC}_{50}=3.24 \mu \mathrm{g} / \mathrm{mL}\right)(P>0.05)$, being the acetone extract of bark the most active extract $\left(\mathrm{EC}_{50}=7.0 \mu \mathrm{g} / \mathrm{mL}\right)$. These results

Table 1. Acetylcholinesterase inhibitory effect and radical scavenging activity of extracts from J. brevifolia.

\begin{tabular}{|c|c|c|}
\hline \multirow{2}{*}{ Plant Extracts } & AChE inhibitory activity & DPPH scavenging activity \\
\hline & $\mathrm{IC}_{50}{ }^{\mathrm{a}}(\mu \mathrm{g} / \mathrm{mL} \pm \mathrm{SD})$ & $\mathrm{EC}_{50}{ }^{\mathrm{b}}(\mu \mathrm{g} / \mathrm{mL} \pm \mathrm{SD})$ \\
\hline \multicolumn{3}{|l|}{ Methanol } \\
\hline Wood & $742 \pm 23$ & $49.6 \pm 0.14$ \\
\hline Bark & $499 \pm 21$ & $33.0 \pm 6.81$ \\
\hline \multicolumn{3}{|l|}{ Acetone } \\
\hline Wood & $825 \pm 294$ & $15.0 \pm 0.74$ \\
\hline Bark & $193 \pm 42$ & $7.0 \pm 0.68$ \\
\hline BHT & - & $31.0 \pm 0.96$ \\
\hline Quercetin & - & $3.24 \pm 0.07$ \\
\hline Ursolic acid & $190 \pm 14$ & - \\
\hline
\end{tabular}

${ }^{a}$ The required concentration of the compound to inhibit $50 \%$ of acetylcholinesterase activity. ${ }^{\text {b}}$ The required concentration of the compound to reduce the $\mathrm{DPPH} \cdot$ concentration to $50 \%$. 
Table 2. In vitro antibacterial activity of extracts from J. brevifolia.

\begin{tabular}{|c|c|c|c|c|c|c|}
\hline \multirow{3}{*}{$\begin{array}{l}\text { Test } \\
\text { organisms }\end{array}$} & \multicolumn{6}{|c|}{ Diameter of inhibition $(\mathrm{mm})($ mean \pm SD) } \\
\hline & \multicolumn{2}{|c|}{ Methanol extract ${ }^{1}$} & \multicolumn{2}{|c|}{ Acetone extract ${ }^{1}$} & \multirow[t]{2}{*}{ Gentamicin $^{2}$} & \multirow[t]{2}{*}{ Chloramphenicol $^{2}$} \\
\hline & Wood & Bark & Wood & Bark & & \\
\hline B. subtilis & 0 & 0 & 0 & $9 \pm 1$ & - & $31 \pm 0.6$ \\
\hline B. cereus & 0 & $10 \pm 0.6$ & $10 \pm 1$ & $11 \pm 0.6$ & $24 \pm 0.6$ & - \\
\hline M. luteus & 0 & 0 & 0 & $10 \pm 0$ & - & $32 \pm 1.5$ \\
\hline E. coli & 0 & 0 & 0 & 0 & - & $17 \pm 0.6$ \\
\hline E. cloacae & 0 & 0 & 0 & 0 & $20 \pm 0$ & - \\
\hline
\end{tabular}

${ }^{1}(200 \mu \mathrm{g} / \mathrm{disc}){ }^{2}(10 \mu \mathrm{g} / \mathrm{disc})$

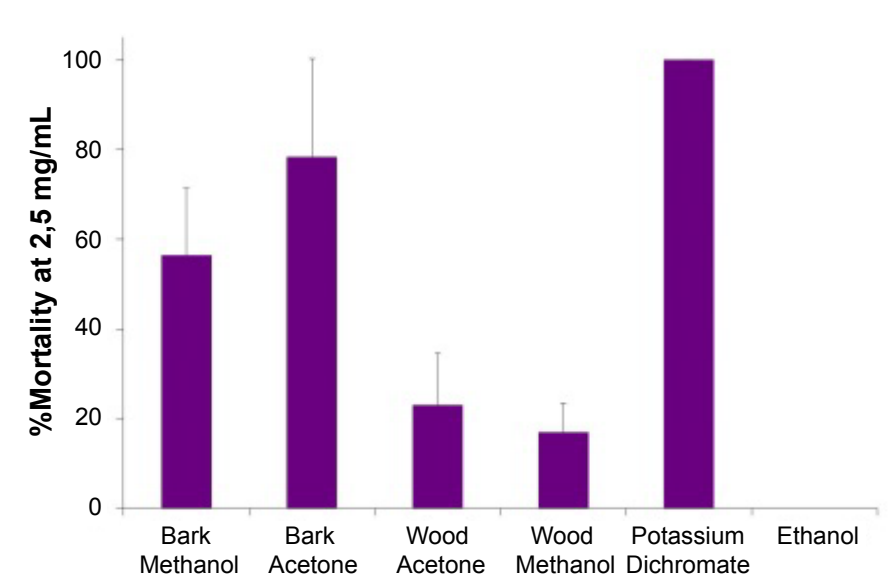

Figure 1. Nauplii mortality (\%) at $2.5 \mathrm{mg} / \mathrm{mL}$ of $J$. brevifolia extracts, reference compound (potassium dichromate) and solvent control (methanol).

suggest that the methanolic bark extract and the acetone extracts of bark and wood could be used for the same industrial applications of quercetin and BHT, two antioxidants with wide applications in the food industry.

The in vitro antibacterial activity of the methanol and acetone extracts from $J$. brevifolia bark and wood were carried out against Gram(+) Bacillus subtilis, B. cereus, Micrococcus luteus and Gram(-) Escherichia coli and Enterobacter cloacae bacteria. As summarized in Table 2, the extracts exhibited antibacterial activity against some of the tested bacteria, in different degrees.

None of the extracts was active against Gram(-) bacteria and the methanolic extract of wood was inactive against all of the bacteria tested. $B$. cereus were the most sensitive bacteria, responding similarly to the wood and bark acetone extracts and to the bark methanolic extract. The acetone extract from bark was the most active, the only one that inhibited all the Gram(+) bacteria, with inhibition zone diameters of $9-11 \mathrm{~mm}$ at $200 \mu \mathrm{g}$ per disc. Although the results are not comparable with those obtained for the reference antibiotics $(24-32 \mathrm{~mm}$ at $10 \mu \mathrm{g}$ per disc), they show that the active extracts tested here are much more active than other acetone and methanolic extracts from other Juniperus species, where inhibition zone diameters are also presented in the order of 8-10 mm but obtained with $400 \mu \mathrm{g}$ per disc [17].

When searching and suggesting new products for application in the food, pharmaceutical and/or cosmetic industries as antioxidant, antibacterial and/or anti-acetylcholinesterasic agents, the toxicity of the product must be taken into account. Therefore the toxicity of all the extracts was evaluated by the brine-shrimp assay (Figure 1). The lethality bioassay with Artemia salina nauplii showed that the wood extracts (methanol and acetone extracts) are the less toxic and present low toxicity, with less than $20 \%$ of mortality at $2.5 \mathrm{mg} / \mathrm{mL}$ (Figure 1 ).

The $\mathrm{LC}_{50}$ values of methanolic and acetone bark extracts were 2.03 and $2.12 \mathrm{mg} / \mathrm{mL}$, respectively, that is approximately 30 -fold higher than the control potassium dichromate $\left(\mathrm{LC}_{50}=69.0 \mu \mathrm{g} / \mathrm{mL}\right)$. The $\mathrm{LC}_{50}$ values for these two extracts are not significantly different based on non-overlapping at $95 \%$ confidence limits. Since these two extracts showed significant antioxidant and anticholinesterasic activities at concentrations much lower than their $\mathrm{LC}_{50}$ values $\left(\mathrm{EC}_{50}=7.0-49.6 \mu \mathrm{g} /\right.$ $\mathrm{mL} ; \mathrm{IC}_{50}=193-825 \mu \mathrm{g} / \mathrm{mL}$ ), it can be concluded that the extracts present low toxicity at the dose at which they can be used as antioxidants and/ or as cholinesterase inhibitors.

\section{Conclusion}

Based on our results, Juniperus brevifolia acetone extract from bark was the most active extract tested showing strong radical scavenging activity, with slight antibacterial effect at a non-toxic concentration and can be used as a natural additive, as food preservative agent or to extend the shelf-life of raw and processed food, replacing some of the commercial synthetic substances currently used for the same purpose.

On the other hand, a significant anti-AChE effect of the acetone bark extract was observed, showing its potential as source of new natural AChEIs drugs to treat neurodegenerative diseases.

Thus, further studies on Juniperus brevifolia acetone bark extract are needed to determine the active compounds responsible for antioxidant and anti-acetylcholinesterase activities.

\section{Authorship and contributorship}

$$
\text { All authors contributed identically }
$$

\section{Acknowledgements}

This work was supported by University of Azores and Direção Regional para Ciência e Tecnologia (DRCT) for funding CIRN, and also supported by Fundação para a Ciência e a Tecnologia (FCT, Portugal), the European Union, QREN, FEDER, COMPETE, for funding the Organic Chemistry Research Unit (QOPNA) (project PEst-C/QUI/UI0062/2013; FCOMP-01-0124-FEDER-037296), CIBIO Research Unit and the Portuguese National NMR Network (RNRMN).

\section{References}

1. Seca AML, Silva AMS (2006) The chemical composition of the Juniperus genus (1970-2004). In: Recent progress in medicinal plants. Govil JN, Singh VK, Eds. Vol 16-Phytomedicines. Houston: Studium Press LLC: 401-522.

2. Moujir L, Seca AM, Silva AM, Barreto MC (2008) Cytotoxic activity of diterpenes and extracts of Juniperus brevifolia. Planta Med 74: 751-753. [Crossref] 
3. Newman DJ, Cragg GM (2012) Natural products as sources of new drugs over the 30 years from 1981 to 2010. J Nat Prod 75: 311-335. [Crossref]

4. Colovic MB, Krstic DZ, Lazarevic-Pašti TD, Bondžic AM Vasic VM (2013) Acetylcholinesterase inhibitors: pharmacology and toxicology. Curr Neuropharmacol $1: 315-335$.

5. Singh M, Kaur M, Kukreja H, Chugh R, Silakari O, et al. (2013) Acetylcholinesterase inhibitors as Alzheimer therapy: from nerve toxins to neuroprotection. Eur J Med Chem 70: 165-188. [Crossref]

6. Pohanka M (2011) Cholinesterases, a target of pharmacology and toxicology. Biomed Pap Med Fac Univ Palacky Olomouc Czech Repub 155: 219-229. [Crossref]

7. Murray AP, Faraoni MB, Castro MJ, Alza NP, Cavallaro V (2013) Natural AChE inhibitors from plants and their contribution to Alzheimer's disease therapy. Curr Neuropharmacol 11: 388-413. [Crossref]

8. Na M, Thuong PT, Bae KH (2011) Natural compounds with antioxidant activity: Recent findings from studies on medicinal plants. Nat Prod Sci 17: 65-79.

9. Pohanka M (2013) Alzheimer's disease and oxidative stress: a review. Curr Med Chem 21: 356-364. [Crossref]

10. Burt S (2004) Essential oils: their antibacterial properties and potential applications in foods: a review. Int J Food Microbiol 94: 223-253. [Crossref]
11. Fernandes P (2006) Antibacterial discovery and development: the failure of success? Nat Biotechnol 24: 1497-1503. [Crossref]

12. Arruda M, Viana H, Rainha N, Neng NR, Rosa JS, et al. (2012) Anti-acetylcholinesterase and antioxidant activity of essential oils from Hedychium gardnerianum Sheppard ex Ker-Gawl. Molecules 17: 3082-3092. [Crossref]

13. BLOIS MS (1958) Antioxidant determinations by the use of a stable free radical. Nature 18: 1199-1200.

14. Bauer AW, Kirby MM, Sherris JC, Truck M (1966) Antibiotic susceptibility testing by a standardized single disk method. Am J Clin Pathol 45: 493-496.

15. Solis PN, Wright CW, Anderson MM, Gupta MP, Phillipson JD (1993) A microwel cytotoxicity assay using Artemia salina (brine shrimp). Planta Med 59: 250-252. [Crossref]

16. Tavares L, McDougall GJ, Fortalezas S, Stewart D, Ferreira RB, et al. (2012) The neuroprotective potential of phenolic-enriched fractions from four Juniperus species found in Portugal. Food Chem 135: 562-570. [Crossref]

17. Öztürk M, Tümen I, Ugur A, Aydogmus-Öztürk F, Topçu G (2011) Evaluation of fruit extracts of six Turkish Juniperus species for their antioxidant, anticholinesterase and antimicrobial activities. J Sci Food Agric 9: 867-876.

18. Orhan N, Orhan IE, Ergun F (2011) Insights into cholinesterase inhibitory and antioxidant activities of five Juniperus species. Food Chem Toxicol 49: 2305-2312. [Crossref]

Copyright: (C2015 Oliveira N. This is an open-access article distributed under the terms of the Creative Commons Attribution License, which permits unrestricted use, distribution, and reproduction in any medium, provided the original author and source are credited. 